\title{
PENENTUAN SUHU, WAKTU, DAN KECEPATAN PUTARAN YANG OPTIMAL PADA PROSES SENTRIFUGASI PENGUJIAN KADAR GEL BERDASARKAN SNI 8385:2017
}

\author{
Determination of Optimum Temperature, Time, and Rotation Speed in the \\ Centrifugation Process of Testing Gel Content Based on SNI 8385: 2017
}

\author{
Herbet Erwin Freddy Manurung ${ }^{1}$ dan Yulia Saptini ${ }^{2}$ \\ 1,2Balai Pengujian Mutu Barang, Kementerian Perdagangan \\ JI Raya Bogor km 26 Ciracas Jakarta Timur \\ E-mail: herbeterwin.777@gmail.com
}

\begin{abstract}
Abstrak
Kadar gel merupakan parameter uji yang penting karena berpengaruh pada proses mastifikasi karet dan sifatsifat-fisik produk karet. Kadar gel dapat ditentukan berdasarkan SNI 8385:2017 dimana pada saat proses sentrifugasi kisaran suhu adalah 0-250 $\mathrm{C}$, kisaran kecepatan putaran $8000-14000 \mathrm{rpm}$, dan kisaran waktu $6-2$ jam. Tujuan dari penelitian ini adalah mencari titik optimum pengujian kadar gel berdasarkan SNI 8385:2017 dikarenakan kisaran suhu, kecepatan, dan waktu sentrifugasi yang cukup lebar. Hasil dari penelitian ini adalah kadar gel optimum dengan adanya variasi perlakuan suhu adalah pada suhu $10^{\circ} \mathrm{C}$ dengan kecepatan $14000 \mathrm{rpm}$ selama 2 jam. Sedangkan kadar gel optimum dngan adanya variasi perlakuan kecepatan putaran dan waktu adalah pada kecepatan putaran 12500 rpm selama 3 jam.
\end{abstract}

Kata kunci: kadar gel, SNI 8385:2917, titik optimum kadar gel

\section{Abstract}

Gel content is an important test parameter because it affects the rubber mastification process and the physical properties of the rubber product. Gel content can be determined based on SNI 8385: 2017 where during the centrifugation process the temperature range is $0-250 \mathrm{C}$, the rotation speed range is $8000-14000 \mathrm{rpm}$, and the time range is 6-2 hours. The purpose of this study was to find the optimum point for gel content testing based on SNI 8385: 2017 due to the wide range of temperature, speed, and timeof centrifugation. The result of this research is that the optimum gel content in the presence of temperature treatment variations is at a temperature of $10^{\circ} \mathrm{C}$ with a speed of $14000 \mathrm{rpm}$ for 2 hours. While the optimum gel content with variations in the rotation speed and time treatment is at the rotation speed of 12500 rpm for 3 hours.

Kata kunci: gel content, SNI 8385:2017, optimun point of gel content

\section{PENDAHULUAN}

Karet alam Hevea Brasiliensis masih menjadi komoditi ekspor unggulan Indonesia. Karet alam merupakan bahan baku penting dalam industri, terutama industri ban. Namun dalam perkembangannya, karet alam juga dapat digunakan pada industri untuk keperluan rumah tangga, kedokteran maupun keteknikan. Menurut Sa'id, Rahman, dan Febriyanti (2005) karet alam memiliki daya elastis atau daya lenting yang sempurna, plastisitas yang baik, kepegasan yang tinggi dan keteraturan geo-metri yang tinggi, yang menambah kuat tarik pada saat direnggangkan namun tidak tahan terhadap oksidasi dan ozon.

Karet alam mengandung sekitar $94 \%$ (cis1,4 poliisoprena) karet hidrokarbon dan $6 \%$ unsur non-karet seperti protein, lipid,karbohidrat, dan lain-lain. Secara alamiah poliisoprena terdiri dari fraksi sol dan fraksi gel (Naimpaiboon, 2013).
Fraksi gel dapat terbentuk karena masa simpan karet dalam waktu yang lama (Nawamawat,2010). Dalam masa simpan yang lama, kadar gel dalam karet alam akan semakin meningkat, dan akan mengalami pengerasan (storage hardening) yang mengakibatkan nilai viskositas mooney meningkat. Peningkatan nilai viskositas mooney akan berpengaruh pada konsumsi energi pada saat proses mastifikasi.

Vachlepi dan Suwardin (2015) menyatakan bahwa proses mastifikasi merupakan proses pelunakan elastomer alam sebagai langkah persiapan pencampuran dengan bahan kimia lain agar tercampur rata atau homogen. Pada proses mastifikasi konsumsi energi mencapai 33-35\% dari keseluruhan proses pada pembuatan kompon karet, sehingga apabila proses mastifikasi dapat dilakukan lebih cepat maka dapat menurunkan biaya produksi. Karet alam dengan viskositas mantap dan viskositas rendah 
tentunya dapat menjadi alternatif pengganti karet alam dengan viskositas tinggi.

Kadar gel dalam karet alam merupakan salah satu faktor penting yang dapat meningkatkan viskositas mooney. Dalam SNI 1903:2011 karet spesifikasi teknis, kadar gel dimasukkan sebagai salah satu syarat mutu pengujian karet untuk jenis karet LoV dimana parameter tersebut tidak dimasukkan pada SNI karet spesifikasi teknis sebelumnya. Tentunya penentuan kandungan gel dalam karet alam tidak hanya dibutuhkan pada karet jenis LoV saja namun diperlukan juga untuk jenis karet alam lainnya.

Penentuan kadar gel dari karet alam spesifikasi teknis dapat dilakukan dengan menggunakan metode SNI 8385:2017. Menurut metode ini pada saat proses sentrifugasi (pemusingan) dapat dilakukan pada suhu $0-25^{\circ} \mathrm{C}$ dengan kecepatan putaran 14000 rpm selama 2 jam atau dengan kecepatan putaran $8000 \mathrm{rpm}$ selama 6 jam. Adanya kisaran suhu sentrifugasi yang lebar dan adanya kemungkinan melakukan pengujian diantara kecepatan putaran serta waktu sentrifugasi yang sudah ditetapkan di SNI mendorong penulis untuk mengetahui di suhu, kecepatan putaran, dan waktu berapakah kadar gel mendapatkan nilai yang optimal.

\section{TINJAUAN PUSTAKA}

Kadar gel karet alam merupakan struktur yang rumit tidak seperti jaringan ikatan silang (crosslink) yang sederhana. Karakterisasi struktur karet alam dengan seleksi pemotongan enzim dan dekomposisi kimiawi, menyatakan adanya protein dan fosfolipid. Adanya interaksi protein dan fosfolipid pada ujung rantai menyebabkan terbentuknya gel pada karet alam ( Naimpaiboon, 2013). Kandungan kadar gel dapat berpengaruh terhadap sifat-sifat fisik produk berbahan dasar karet. Menurut Naimpabon, dkk (2013) kenaikan kadar gel akan menaikkan nilai viskositas mooney. Pada karet alam vulkanisat yang tidak terisi, meningkatnya kadar gel menyebabkan nilai tegangan akan naik pada saat regangan yang lebih kecil. Sedangkan pada karet alam vulkanisat yang diisi carbonblack kandungan gel akan menyebabkan penurunan densitas ikatan silang dan kekuatan tarik. Vachlepi dan Suwardin (2015) menyatakan bahwa nilai viskositas mooney berkorelasi dengan kandungan gelnya. Kandungan gel dalam karet alam dapat diturunkan dengan penambahan zat aditif. Selain itu menurut Puspitasari, Budianto, dan Maspanger (2015) adanya kandungan gel akan menghambat proses modifikasi karet alam.

Penetapan kandungan gel dari karet alam dapat dilakukan dengan cara penyaringan, ekstraksi dan sentrifugasi. Puspitasari dan Cifriadi
(2017), Yusniwati (2016) menentukan kandungan gel dengan metode penyaringan. Sampel karet alam dilarutkan dalam larutan kloroform atau pelarut lain kemudian residu hasil penyaringan dikeringkan. Riyajan dan Sukhlaaied (2013) menetapkan kandungan gel dengan cara ekstraksi menggunakan soxhlet. Sampel diekstraksi dalam toluena mendidih dan dalam air mendidih. Hasil ekstraksi kemudian dikeringkan. Thuong, Nghia, dan Kanawara (2018), Tangpakdee dan Tanaka, Subbaiah,dkk (2016), Ehabe dan Bonfils (2011) menggunakan metode sentrifugasi dalam menentukan kadar gel pada karet alam. Sampel karet alam dilarutkan dalam toluena kemudian di sentrifugasi. Hasil sentrifugasi kemudian dikeringkan. Kandungan gel dihitung sebagai presentase kandungan kering terhadap bobot sampel baik dengan cara penyaringan, ekstraksi, maupun sentrifugasi.

Naimpaiboon, Amnuaypornsri, dan Sakdapipanich (2015) menentukan kandungan gel berdasarkan ISO/DIS 17278:2012 dengan metode sentrifugasi pada kecepatan putaran $14000 \mathrm{rpm}$ selama 2 jam. Metode penentuan kadar gel dengan ISO/DIS 17278:2012 ini diadopsi menjadi standar SNI 8385:2017.

Sentrifugasi merupakan proses pemisahan partikel padat dari cairan dengan menggunakan prinsip gravitasi dan sentrifugal dimana densitas partikel padat harus lebih besar daripada densitas cairan agar partikel padat dapat dipisahkan dari partikel cairnya. Pada pemisahan padat cair, partikel padat akan terpisah dibagian atau bagian terluar sentrifus, cairan yang memiliki densitas yang lebih tiggi akan terpisah dibagian atau dibagian terluar sentrifuse hal ini diakibatkan oleh gaya gravitasi. Semakin besar densitas maka akan semakin besar pula gaya gravitasi yang diberikan. Sehingga akan semakin cenderung menarik kebawah (Istianah, Wardani, dan Sriherfyna, 2018).

Untuk menjamin keabsahan hasil pengujian dapat dilakukan dengan berbagai cara. Salah satunya adalah presisi. Presisi adalh ukuran yang menunjukkan derajat kesesuaian antara hasil uji individual, diukur melalui penyebaran hasil individual dari rata-rata jika prosedur diterapkan secara berulang pada sampe-sampel yang diambil dari campuran yang homogen. Presisi dapat dinyatakan sebagai keterulangan (repitabilitas) dan ketertiruan (reprodusibilitas). Repitabilitas adalah kepresisian metode jika dilakukan berulang kali oleh analis yang sama, kondisi yang sama dan dalam interval waktu yang pendek. Reprodusibilitas adalah kepresisian metode jika dilakukan berulang kali dengan analis yang berbeda, kondisi yang berbeda atau peralatan yang berbeda. Metode sederhana untuk mengetahui nilai presisi adalah 
dengan menghitung standar deviasi dari beberapa pengukuran. Menurut Boque, et.al (2002), repitabilitas dinyatakan sebagai :

$$
r=2,8 \mathrm{Sr}
$$

Sr adalah standar deviasi repitabilitas

$r$ adalah unit repitabilitas

Sedangkan reproducibilty standar deviasi dinyatakan sebagai :

$$
R=2,8 S R
$$

$R$ adalah unit reprodusibilitas

SR adalah standar deviasi reprodusibilitas

Dalam SNI 8385:2017, data presisi kandungan gel dalam laboratorium yang dinyatakan sebagai repitabilitas relatif ( $r$ ) disajikan pada Tabel 1. Sedangkan data presisi antar laboratorium yang dinyatakan sebagai reprodusibilitas relatif $(R)$ disajikan pada Tabel 2 .

Tabel 1. Repitabilitas kandungan gel

\begin{tabular}{|c|c|c|c|c|}
\hline \multirow{2}{*}{ Bahan } & \multirow{2}{*}{$\begin{array}{c}\text { Mean } \\
\text { (\%) }\end{array}$} & \multicolumn{3}{|c|}{ Dalam Laboratorium } \\
\cline { 3 - 5 } & Sr & $\mathbf{r}$ & $(\mathbf{r})$ \\
\hline A & 0,80 & 0,14 & 0,39 & 48,8 \\
\hline B & 5,20 & 0,26 & 0,75 & 14,4 \\
\hline C & 8,20 & 0,56 & 1,57 & 19,1 \\
\hline
\end{tabular}

Tabel 2. Reprodusibilitas kandungan gel

\begin{tabular}{|c|c|c|c|c|}
\hline \multirow{2}{*}{ Bahan } & \multirow{2}{*}{$\begin{array}{c}\text { Mean } \\
\text { (\%) }\end{array}$} & \multicolumn{3}{|c|}{ Antar Laboratorium } \\
\cline { 3 - 5 } & SR & $\mathbf{R}$ & (R) \\
\hline A & 0,80 & 0,45 & 1,27 & 158,8 \\
\hline B & 5,20 & 1,52 & 4,31 & 82,9 \\
\hline C & 8,20 & 2,02 & 5,71 & 69,6 \\
\hline
\end{tabular}

A adalah bahan dengan kandungan gel rendah $B$ adalah bahan dengan kandungan gel medium $\mathrm{C}$ adalah bahan dengan kandungan gel tinggi

\section{METODE PENELITIAN}

Penelitian ini dilakukan pada tanggal 27 Januari sampai dengan tanggal 26 Februari 2020. Pengambilan data dilakukan di laboratorium uji Fisika Mekanika Balai Pengujian Mutu Barang. Sampel yang digunakan adalah SIR 3L yang berasal dari PT. Indo Java Rubber Company.

Penentuan kadar gel dilaksanakan dengan metode pengujian sesuai SNI 8385:2017. Peralatan utama yang digunakan adalah tabung sentrifugasi ukuran $50 \mathrm{~mL}$, alat sentrifugasi merek Tomy tipe CAX-370 dan oven merek Memmert. Bahan kimia yang digunakan yaitu toluena dan aseton merek Merck dengan kualitas untuk pengujian.

Pada penelitian ini, pada saat proses sentrifugasi dilakukan variasi perlakuan terhadap suhu pada saat proses sentrifugasi dengan kecepatan putaran tetap yaitu $14.000 \mathrm{rpm}$ selama 2 jam. Dalam SNI 8385:2017, untuk penentuan kadar gel, tahapan proses sentrifugasi dapat dilakukan pada suhu $0-25^{\circ} \mathrm{C}$, namun pada saat dilakukan pengujian pada suhu $20^{\circ} \mathrm{C}$, tabung sentrifugasi pecah pada menit ke-30, sehingga variasi suhu pada penelitian ini dibatasi pada suhu $-5^{\circ} \mathrm{C}, 0^{\circ} \mathrm{C}, 5^{0} \mathrm{C}, 10^{\circ} \mathrm{C}, 15^{\circ} \mathrm{C}$.

Selain itu, pada penelitian ini juga dilakukan variasi perlakuan pada kecepatan putaran alat sentrifugasi dan variasi waktu pada suhu tetap berdasarkan hasil penelitian dengan variasi perlakuan suhu. Variasi tersebut adalah sebagai berikut : sentrifugasi selama 2 jam dengan kecepatan putaran 14.000 rpm, sentrifugasi selama 3 jam kecepatan putaran $12.500 \mathrm{rpm}$, sentrifugasi selama 4 jam kecepatan putaran $11.000 \mathrm{rpm}$, sentrifugasi selama 5 jam kecepatan putaran $9500 \mathrm{rpm}$, sentrifugasi selama 6 jam kecepatan putaran 8000 rpm.

Prosedur kerja penentuan kadar gel pada karet SIR dimulai dengan penimbangan sampel sebanyak 0,1 gram. Kemudian sampel dimasukkan ke dalam botol kaca dengan penambahan toluena sebanyak $30 \mathrm{~mL}$ dan disimpan dalam ruangan gelap selama 16 - 20 jam. Setelah itu, sampel beserta toluena dipindahkan ke tabung sentrifugasi dan dikocok. Apabila volume toluena dalam tabung berkurang karena penguapan, dapat ditambahkan toluena segar sehingga masing-masing tabung mempunyai volume yang sama. Sentrifugasi larutan sampel sesuai dengan rancangan pengujian. Setelah selesai sentrifugasi, dalam tabung akan terbentuk gel. Pindahkan gel yang terbentuk dalam wadah alumunium yang sudah diketahui bobotnya. Untuk memudahkan gel lepas dari tabung dapat ditambahkan aseton 1-3 $\mathrm{mL}$. Gel yang terbentuk kemudian dikeringkan dalam oven pada suhu $110^{\circ} \mathrm{C}$ selama 1 jam sampai bobot tetap. Kadar gel dapat dihitung dengan formula sebagai berikut :

$$
G=\frac{\left(m_{2}-m_{1}\right)}{m_{0}} \times 100
$$

$G$ adalah kadar gel, sebagai (\%)

$m_{0}$ adalah massa dari potongan uji awal, dalam gram (g)

$m_{1}$ adalah massa wadah kosong, dalam gram (g) $m_{2}$ adalah massa dari wadah berisi endapan kering, dalam gram (g) 
Presisi hasil pengujian kandungan gel dinyatakan sebagai repitabilitas relatif $(r)$ yang dihitung dari :

$$
(r)=\frac{r}{\text { Mean }} \times 100
$$

(r) adalah repitabilitas relatif, dalam presentase (\%)

$\mathrm{R}$ adalah unit repitabilitas

Mean adalah nilai rata-rata hasil pengujian

\section{HASIL DAN PEMBAHASAN}

Hasil pengujian yang disajikan dalam Tabel 3 dan Tabel 4 merupakan nilai rata-rata dalam setiap variasi perlakuan. Hasil pengujian kadar gel dengan variasi suhu pada kecepatan putaran tetap sebesar $14000 \mathrm{rpm}$ dan waktu tetap selama 2 jam sesuai ketentuan didalam SNI 8385:2017 disajikan pada Tabel 3 dan Gambar 1.

Tabel 3. Hasil pengujian kadar gel dengan variasi suhu

\begin{tabular}{|c|c|c|}
\hline $\begin{array}{c}\text { Variasi Suhu } \\
\left({ }^{\circ} \mathbf{C}\right)\end{array}$ & $\begin{array}{c}\text { Kadar Gel } \\
(\%)\end{array}$ & $\mathbf{( r )}(\%)$ \\
\hline-5 & 8,88 & 19,7 \\
\hline 0 & 9,61 & 16,9 \\
\hline 5 & 13,26 & 16,4 \\
\hline 10 & 13,59 & 12,1 \\
\hline 15 & 13,10 & 11,9 \\
\hline
\end{tabular}

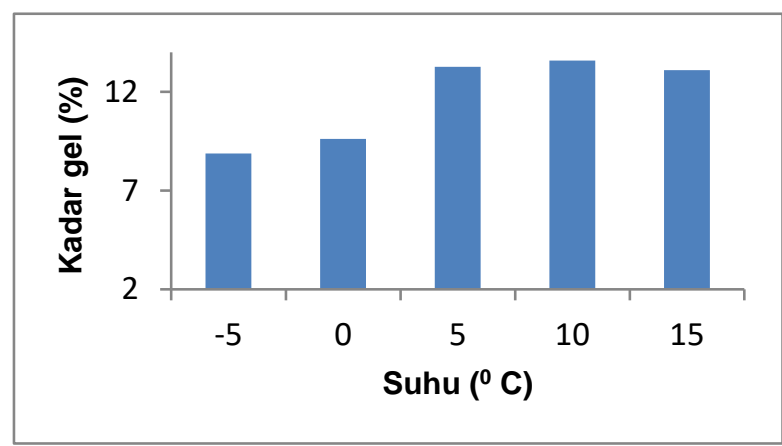

Gambar 1. Hasil pengujian kadar gel dengan variasi suhu

Pada Tabel 3, hasil pengujian kadar gel pada SIR 3L pada suhu $10^{\circ} \mathrm{C}$ memberikan hasil tertinggi yaitu sebesar $13,59 \%$. Sedangkan pengujian pada suhu $-5^{0} \mathrm{C}$ memberikan hasil terendah sebesar 8,92 \%. Dalam SNI 8385:2017 Lampiran $A$, contoh uji dengan kandungan gel tinggi yaitu $\geq 8,20 \%$ mempunyai nilai repitabilitas (r) sebesar $19,1 \%$. Nilai repitabilitas kadar gel pada suhu $-5^{\circ} \mathrm{C}$ sebesar $19,7 \%$ melebihi nilai repitabilitas di SNI 8385:2017, sehingga nilai pengujian pada suhu ini tidak dapat diterima. Hal ini sesuai dengan ketentuan dalam standar SNI yang mensyaratkan suhu pada saat proses sentrifugasi adalah $0-25^{\circ} \mathrm{C}$. Untuk nilai kandungan gel pada suhu $0^{\circ} \mathrm{C}, 5^{\circ} \mathrm{C}, 10^{\circ} \mathrm{C}$, dan $15^{0} \mathrm{C}$ memenuhi syarat keberterimaan presisi yaitu $<19,1 \%$.

Pada Gambar 1 terlihat bahwa kadar gel meningkat dengan penambahan suhu sentrifugasi sampai pada suhu $10^{\circ} \mathrm{C}$, kemudian menurun pada suhu $15^{\circ} \mathrm{C}$. Oleh karena itu suhu optimum pada proses sentrifugasi untuk penentuan kadar gel dalam karet alam adalah pada suhu $10^{\circ} \mathrm{C}$. Untuk selanjutnya pengujian dengan variasi perlakuan kecepatan putaran dan waktu sentrifugasi dilakukan pada suhu $10^{\circ} \mathrm{C}$ yang merupakan titik optimumnya.

Hasil pengujian kadar gel dengan variasi kecepatan putaran alat sentrifugasi dan variasi waktu dengan suhu $10^{\circ} \mathrm{C}$ disajikan dalam Tabel 4 dan Gambar 2.

Tabel 4. Hasil pengujian kadar gel dengan variasi kecepatan putaran dan waktu

\begin{tabular}{|c|c|c|c|}
\hline \multicolumn{2}{|c|}{ Variasi Perlakuan } & \multirow{2}{*}{ Kadar } & \multirow{2}{*}{ (r) (\%) } \\
\cline { 1 - 2 } $\begin{array}{c}\text { Kecepatan } \\
\text { Putaran } \\
\text { (rpm) }\end{array}$ & $\begin{array}{c}\text { Waktu } \\
\text { (Jam) }\end{array}$ & $\begin{array}{c}\text { gel (\%) } \\
\text { (rpm }\end{array}$ & \\
\hline 14.000 & 2 & 13,59 & 12,1 \\
\hline 12.500 & 3 & 15,03 & 15,7 \\
\hline 11.000 & 4 & 13,93 & 13,5 \\
\hline 9500 & 5 & 13,77 & 14,2 \\
\hline 8000 & 6 & 12,72 & 11,5 \\
\hline
\end{tabular}

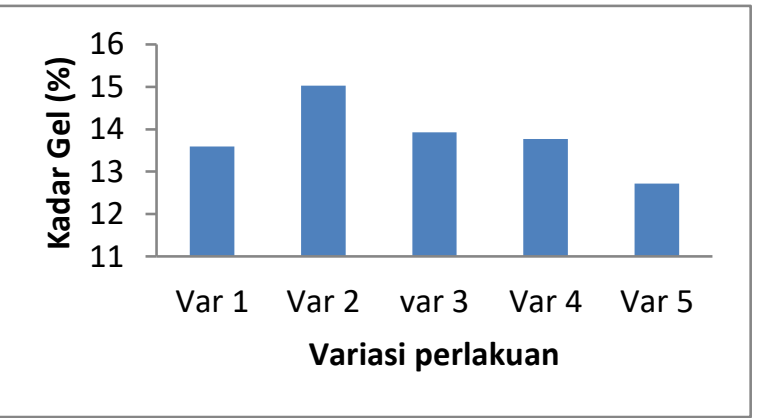

Gambar 2. Hasil pengujian kadar gel dengan variasi kecepatan putaran dan waktu Keterangan:

Var 1 adalah sentrifugasi pada kecepatan putran 14000 rpm selama 2 jam

Var 2 adalah sentrifugasi pada kecepatan putran $12.500 \mathrm{rpm}$ selama $3 \mathrm{jam}$

Var 3 adalah sentrifugasi pada kecepatan putran $11.000 \mathrm{rpm}$ selama $4 \mathrm{jam}$

Var 4 adalah sentrifugasi pada kecepatan putran 9500 rpm selama 5 jam 
Var 2 adalah sentrifugasi pada kecepatan putran 8000 rpm selama 6 jam

Berdasarkan Tabel 4 dan Gambar 2, hasil pengujian kadar gel pada SIR $3 \mathrm{~L}$ dengan kecepatan putaran $12.500 \mathrm{rpm}$ selama 3 jam memberikan hasil tertinggi yaitu sebesar 15,03\%. Sedangkan pengujian pada kecepatan 8000 rpm selama 6 jam memberikan hasil terendah sebesar $12,72 \%$. Nilai repitabilitas pada pengujian dengan berbagai variasi kecepatan putaran dan variasi waktu <19,1\% sehingga dapat dikatakan bahwa hasil pengujian dapat diterima. Pada Gambar 2 terlihat bahwa kadar gel optimum terjadi bukan pada titik seperti yang disebutkan dalam SNI 8385:2017, tetapi titik optimum pengujian terjadi diantara 2 titik yang menjadi ketentuan dalam SNI yaitu pada kecepatan putaran 12500 rpm selama 3 jam.

\section{KESIMPULAN}

Dari hasil penelitian dapat disimpulkan bahwa hasil pengujian kadar gel berdasarkan SNI 8385:2017 dengan variasi suhu dapat diterima pada suhu $0^{0} \mathrm{C}, 5^{0} \mathrm{C}, 10^{\circ} \mathrm{C}$, dan $15^{\circ} \mathrm{C}$, Sedangkan hasil pengujian kadar gel dengan variasi kecepatan putaran dan variasi waktu pada saat tahapan proses sentrifugasi dapat diterima pada semua variasi perlakuaan. Hasil pengujian kadar gel paling besar atau optimal didapatkan dengan variasi suhu dengan kecepatan putaran tetap pada $14000 \mathrm{rpm}$ dan waktu tetap selama 2 jam, pada suhu $10^{\circ} \mathrm{C}$. Sedangkan kandungan gel pada variasi kecepatan putaran 12500 rpm selama 3 jam pada suhu tetap sebesar $10^{\circ} \mathrm{C}$ memberikan hasil pengujian yang tertinggi atau optimal.

\section{UCAPAN TERIMA KASIH}

Penulis mengucapkan terima kasih kepada Balai pengujian Mutu Barang Kementerian Perdagangan yang telah memberikan dukunga biaya, sarana dan prasarana dalam melakukan penelitian ini. Penulis turut berterima kasih kepada Sdr. Arun dan Diana Mulyani, Mahasiswa Jurusan Kimia, Universitas Islam Indonesia atas bantuan dalam menyelesaikan penelitian ini.

\section{DAFTAR PUSTAKA}

Boque, R. \& et.al. (2002). Validation of analytical methods. Grasas y Aceites. Vol 53 Fasc 1, 128 - 143. Tarragona, Spain
Ehabe, E \& Bonfils, F. (2011). Novel Insught into the gel phase of Hevea Natural Rubber. Journal of Rubber Research.

Istianah, N., Wardani, A.K., \& Sriherfyna,F.H . (2018). Teknologi Bioproses. Universitas Brawijaya Press, Malang

Kawahara, S., Nghia, P.T., \& Thuong, N.T. (2018). Factors influencing green strength of commercial natural rubber. Green Process Synth, 8, 399 - 408.

Nawamawat, K., Sakdapipanich, J.T., \& Ho, C.C. (2010). Effect of deproteinized methods on the properties of natural rubber latex during storage. Macromolecular Symposia, 288, 95-103.

Nimpaiboon, A., Amnuaypornsri, S., \& Sakdapipanich, J (2013). Influence of gel content on the physical properties of the unfilled and carbon black filled natural rubber vulcanizated. Polymer Testing.

Nimpaiboon, A., Amnuaypornsri, S., \& Sakdapipanich, J (2015). Role of gel content on the structural change of masticated natural rubber. Advanced Materials, Vo 844, pp 101-104. Trans Tech Publications, Switzerland.

Puspitasari,S., Budiando, E. \& Maspanger, D.R. (2015). Kajian modifikasi kimia secara kopolimerisasi cangkok pada pembuatan karet alam termoplastik. Warta perkaretan, 34 (1), 65-76.

Puspitasari,S. \& Cifriadi, A. (2017). Katalitik hidrogenasi lateks karet alam dengan senyawa diimida pada skala semi pilot. Majalah Kulit, Karet, dan Plastik, 33(2), 8592.

Riyajan, S., \& Sukhlaaied. (2013). Effect of chitosan content on gel content of epoxized natural rubber grafted with chitosan in latex form. Materials Science and Engineering $C$, 33, 1041-1047.

Sa'id,E.G., Rahman, N., Febriyanti, L. (2005). Pengaruh hidrogenasi dalam fase lateks pada karet alam Hevea Brasiliensis. Jurnal Teknologi Industri Pertanian, Vol. 14(3), 80-86.

Subbaiah, Y. \& et.al. (2016). Influence of submicron tiny gel rubber particles on the estimation of grafting and rubber efficiency in high-impact polystyrene. Journal of elastomer and Plastics, 1-12.

Tangpakdee, J. \& Tanaka, Y. (1997). Characterization of sol and gel in Hevea Tokyo University of Agricultural and Technology. Tokyo: Japan. 
Vachlepi, A. \& Suwardin, D. (2015). Penggunaan garam ammonium dalam produksi karet viskositas rendah dari lateks. Jurnal Penelitian Karet, 33(2), 193-202.
Yusniwati. (2016). Determination of gel content by incorporating imidazolium based ionic liquid as a co-solvent for expodized natural rubber (ENR). Unpublished manuscript, University of Malaya, Kuala Lumpur, Malaysia. 